International Journal of Engineering \& Technology, $7(2.23)(2018) 443-445$
International Journal of Engineering \& Technology
Website: www.sciencepubco.com/index.php/IJET
Research paper

\title{
A Comprehensive Study on Mechanical Properties of Nominal Grade Concrete Using Copper Slag as Partial Replacement to Fine Aggregate
}

\author{
USHAKRANTI J ${ }^{1}$, SRINIVASU $\mathrm{K}^{2}$, NAGA SAI ${ }^{3}$ \\ ${ }^{1}$ Asst. Professor, Department Of Civil Engineering, R.V.R\&J.C. College Of Engineering, Guntur, A.P., India \\ ${ }^{2}$ Professor, Department Of Civil Engineering, R.V.R\&J.C. College Of Engineering, Guntur-522019, A.P. \\ ${ }^{3}$ Asst. Professor, Department Of Civil Engineering, Aditya College Of Engineering \& Technology, Kakinada, A.P., India \\ *Corresponding Author E-Mail: Usha.Jujjuri@Gmail.Com
}

\begin{abstract}
Currently situation, improvement of infrastructure has created an excessive demand for herbal sand, which makes it greater expensive and leads to environmental imbalances. The utilization of suitable sustainable choice materials proves that it is the most efficacious choice to traditional concrete materials and can take care of the surrounding environment. Copper slag is an industrial byproduct of copper production. Copper slag is a high-gravity glassy granular material. This paper reports some experimental studies on the outcome of partially changed sand from impact of copper slag on the mechanical houses of concrete. M30 concrete adopts copper slag plan and partly substitutes high-quality combination fines by means of $0 \%, 10 \%, 20 \%, 30 \%, 40 \%, 50 \%, 60 \%, 80 \%$ and $100 \%$. The mechanical properties of concrete measured in the laboratory encompass compressive strength, split tensile strength and bending tensile strength. The have an impact on of partly replacing the quality aggregates with copper slag on the compressive strength, the cut up tensile power of the cylinder and the bending power of the prism has been evaluated. Water absorption assessments have been also conducted to report the impact of copper slag on the absorption price of concrete. Test results affords that it is feasible to utilize copper slag as best aggregate in concrete.
\end{abstract}

Keywords: compression strength test; concrete; Copper slag; fine aggregate; replacement; split tensile strength

\section{Introduction}

The utilization of industrial waste or secondary materials promotes the manufacture of cement and concrete in the construction sector. Various industries are producing new by-products and waste. Dumping of waste can cause environmental and fitness problems. Therefore, reuse of waste is a large plausible for the concrete manufacturing. For many years, by-products such as fly ash, silica sinks, and slag have been regarded as waste. Concrete made of this fabric suggests elevated operability and sturdiness compared to everyday concrete and it has been used for the construction of electric powered power, chemical vegetation and underwater structures. In present day decades, in-depth research has been geared up to discover all viable methods for reuse. Copper slag is received as waste from the waste industry. Conduct a survey to explore the possibility copper slag as a substitute for sand in a concrete mixture. In the current situation, automobile effusions and sand extraction have grown to be a foremost concern due to environmental risks and serious imbalances in the ecosystem.

Some studies have been conducted to limit the serious have an effect on on the environment, using by-products such as copper slag as a partial alternative for great aggregates. There are a number experiences in utilizing copper slag as a subdivision of pleasant aggregates. Copper slag is a substance that is considered as waste. It can have a shiny future in the construction enterprise and can partly or completely change cement or aggregate. It is a derivative of the copper smelting and refining process. About 2.2-3.0 lots of copper slag is processed as a derivative when producing one ton of copper. At present, Nissan has about 2,600 tons of copper slag, with a cumulative whole of about 1.5 million tons. [1] If we can make use of copper slag alternatively of natural sand, then we can successively acquire an alternative to sand, which is an environmentally friendly and within your budget material.

\section{Literature Review}

Leema Rose \& Suganya examined Copper slag as a partial replacement for concrete fines in terms of strength and durability .The main purpose of this research was to perceive the strength and durability of concrete, where copper slag was used to partially replace $10 \%, 20 \%, 30 \%$ and $40 \%$ of the fine aggregate. Their conclusion is that adding copper slag to the concrete will increase the density of the concrete. The compression test results presents that the percentage of copper slag added to the strength of concrete is increased by $30 \%$ relative to the weight of the fine aggregate, and the copper slag strength of the design mixture 1 is 45.42 $\mathrm{N} / \mathrm{mm} 2: 1.4: 2.6$ to maintain the W/C ratio of 0.4 [ 2]. Srinivasu, Kranti, Nagasai, and Saikumar studied the compressive strength properties and effects of copper slag as a partial substitute for concrete fines. Using two different types of concrete grades $\mathrm{M} 30$ and M40, the copper slag replacement rates range from 0 to $100 \%$. The percentage of sand rearrangement is $0 \%, 10 \%, 20 \%$, $30 \%, 40 \%, 50 \%, 60 \%, 80 \%$ and $100 \%$. After the mold was cast, the compressive strength of the concrete was tested for 7 days and 
28 days. It has been observed that the compressive strength of the above graded concrete increases. For M30 concrete, $50 \%$ of the highest compressive strength in 7 days was $39.105 \mathrm{Mpa}$ instead of copper slag, and $28 \%$ of the copper slag to attain the maximum compressive strength was $10 \%$. It was found to be about $44.66 \mathrm{MPa}$, which is the nominal value $(29.87) \mathrm{N} / \mathrm{mm} 2$ and $41.65 \mathrm{~N} / \mathrm{mm} 2$ ) For M40 concrete, $70 \%$ maximum compressive strength reached $20 \%$ instead of copper slag $44.44 \mathrm{MPa}, 28$ days reached the highest compressive strength $50 \%$ placed copper slag and found about 53.105MPa, with the standard Compare the mixing (32.33N/mm2 and $47.11 \mathrm{~N} / \mathrm{mm} 2)$. [3] Zerdi conducted Experimental study on the performance of concrete with fine aggregate instead of copper slag. The fine aggregate was replaced with the percentage of $0 \%$ (control mixture), $20 \%, 40 \%$ and $60 \%$ copper slag weight. The properties of fresh concrete and hardened concrete were tested. The compressive strength was measured on days 3, 7, 14 and 28. With the utilization of copper slag in concrete, properties such as workability and density increase. The insertion of $40 \%$ copper slag to the concrete as a fine aggregate rearrangement can enhance the strength properties of the concrete For M20 concrete, it is $25.58 \mathrm{~N} / \mathrm{mm} 2$ in 28 days. [4]. Singer and Bath studied the utilization of copper slag as fines in their paper a case study. Reliance on natural aggregates as the main source of concrete aggregates can be substituted with artificially produced aggregates or artificial aggregates produced from industrial waste, and provide alternatives for the construction industry. The results show that the use of copper slag in concrete can increase the bending strength by about $17 \%$ and control the flexural strength of the mixture. It is suggested that up to $40 \%$ of the copper slag be used as a substitute for fines. After the trend of further change in bending strength was decreased, the maximum bending strength at $40 \%$ substitution $(6.67 \mathrm{~N} / \mathrm{mm} 2)$ was observed. [5]

\section{Experimental Program}

The experimental layout pursuits to affect the mechanical residences of concrete by using copper slag as a partial alternative for $10 \%, 20 \%, 30 \%, 40 \%, 50 \%$ and $60 \%, 80 \%$ and a hundred percent of the nice aggregate. For every test, the average of two samples from each combination was tested at each age of maturation and the average used to be used for analysis. The compressive strength used to be calculated at 7 days and 28 days. Calculate the break up tensile strength and bending strength at 28 days of age.

\subsection{Mix Proportion}

According to the Indian general specification BIS 10262:2009, a control mixture was designed for M30 grade concrete. The different concrete mixtures had been made of copper slag alternatively of fantastic aggregates with mass fractions of $0 \%, 10 \%, 20 \%$, $30 \%, 40 \%, 50 \%, 60 \%, 80 \%$ and $100 \%$, respectively. The water/cement $(\mathrm{w} / \mathrm{c})$ ratio in all combinations was once maintained at 0.43 .

\section{Results and Discussions}

Here are the results acquired by testing various specimens

\subsection{Compressive Strength}

A total of 54 cubes measuring one hundred fifty $\mathrm{x}$ a hundred and fifty $\mathrm{x}$ one hundred fifty $\mathrm{mm}$ had been solid and tested on a 200 ton capability compression tester. After 24 hours the concrete cubes were demolded and cured beneath water for 28 days.
Table 1 Compressive strength 28 days of curing

\begin{tabular}{|c|c|c|}
\hline S.No & \% replacement of copper slag & $\begin{array}{c}\text { Compressive strength } \\
\text { after 28 days } \\
\left(\mathrm{N} / \mathrm{mm}^{2}\right)\end{array}$ \\
\hline 1 & $0 \%$ & 38.80 \\
\hline 2 & $10 \%$ & 39.89 \\
\hline 3 & $20 \%$ & 40.70 \\
\hline 4 & $30 \%$ & 41.44 \\
\hline 5 & $40 \%$ & 42.95 \\
\hline 6 & $50 \%$ & 43.33 \\
\hline 7 & $60 \%$ & 34.44 \\
\hline 8 & $80 \%$ & 31.39 \\
\hline 9 & $100 \%$ & 27.66 \\
\hline
\end{tabular}

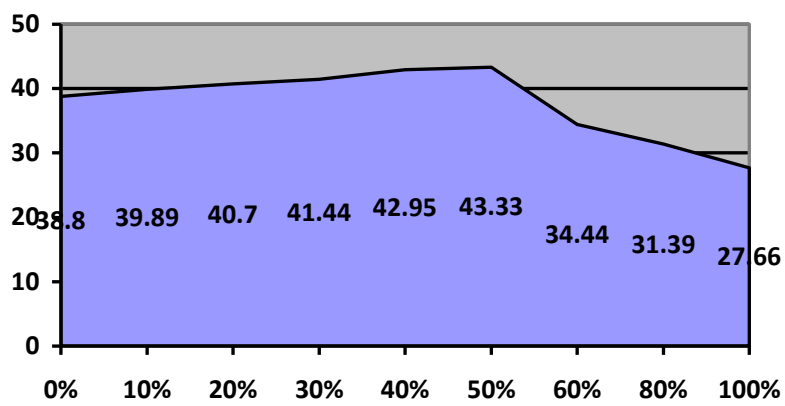

Fig.1 graph showing compressive strength after 28 days of curing

\subsection{Split tensile Strength}

Table 2 Split tensile strength 28 days of curing

\begin{tabular}{|c|c|c|}
\hline S.No & $\begin{array}{c}\text { \% replacement of copper } \\
\text { slag }\end{array}$ & $\begin{array}{c}\text { Split tensile strength } \\
\text { after } \\
28 \text { days } \\
\left(\mathrm{N} / \mathrm{mm}^{2}\right)\end{array}$ \\
\hline 1 & $0 \%$ & 3.01 \\
\hline 2 & $10 \%$ & 3.32 \\
\hline 3 & $20 \%$ & 3.07 \\
\hline 4 & $30 \%$ & 3.45 \\
\hline 5 & $40 \%$ & 3.66 \\
\hline 6 & $50 \%$ & 2.50 \\
\hline 7 & $60 \%$ & 3.73 \\
\hline 8 & $80 \%$ & 3.31 \\
\hline 9 & $100 \%$ & 2.64 \\
\hline
\end{tabular}

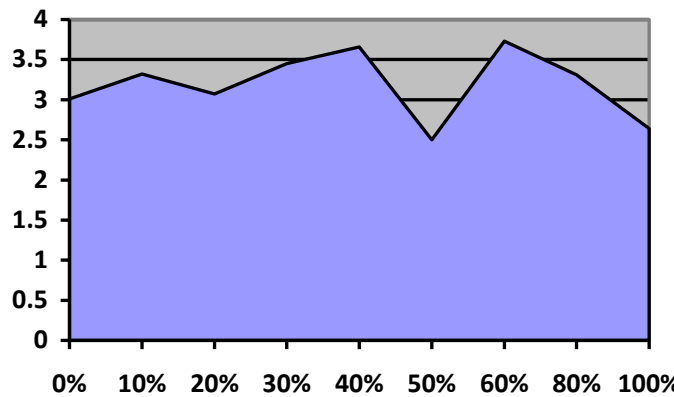

$\square$ East

Fig. 2 graph showing split tensile strength after 28 days of curing

\subsection{Flexural Strength}

Table 3 flexural strength 28 days of curing

\begin{tabular}{|c|c|c|}
\hline S.No & $\begin{array}{c}\text { \% replacement of copper } \\
\text { slag }\end{array}$ & $\begin{array}{c}\text { Flexural strength } \\
\text { after } \\
28 \text { days } \\
\left(\mathrm{N} / \mathrm{mm}^{2}\right)\end{array}$ \\
\hline 1 & $0 \%$ & 4.80 \\
\hline 2 & $10 \%$ & 6.35 \\
\hline 3 & $20 \%$ & 7.00 \\
\hline 4 & $30 \%$ & 7.23 \\
\hline 5 & $40 \%$ & 7.73 \\
\hline 6 & $50 \%$ & 6.05 \\
\hline
\end{tabular}




\begin{tabular}{|l|c|c|}
\hline 7 & $60 \%$ & 6.27 \\
\hline 8 & $80 \%$ & 5.46 \\
\hline 9 & $100 \%$ & 4.42 \\
\hline
\end{tabular}

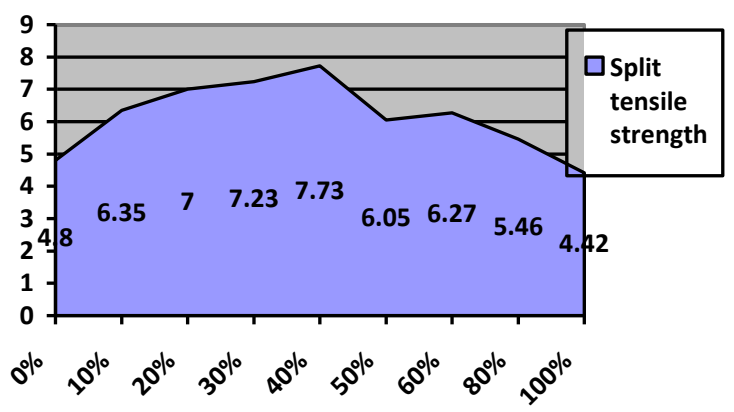

Fig. 3 graph showing flexural strength after 28 days

Table 4 Water absorption test results

\begin{tabular}{|c|c|c|c|c|c|}
\hline S.No & $\begin{array}{c}\text { Mix } \\
\text { ID }\end{array}$ & $\begin{array}{l}\text { Saturated } \\
\text { Weight }\end{array}$ & $\begin{array}{l}\text { Oven } \\
\text { Dried }\end{array}$ & \multicolumn{2}{|c|}{$\begin{array}{l}\text { Saturated water absorp- } \\
\text { tion test at } 28 \text { Days (\%) }\end{array}$} \\
\hline \multirow[t]{4}{*}{1} & \multirow{4}{*}{$\mathrm{CC}$} & 8.510 & 8.445 & 0.776 & \multirow{4}{*}{1.506} \\
\hline & & 8.610 & 8.393 & 2.585 & \\
\hline & & 8.340 & 8.180 & 1.956 & \\
\hline & & 8.530 & 8.470 & 0.708 & \\
\hline \multirow[t]{4}{*}{2} & \multirow[t]{4}{*}{$20 \%$} & 8.830 & 8.712 & 1.351 & \multirow[t]{4}{*}{1.475} \\
\hline & & 8.570 & 8.421 & 1.769 & \\
\hline & & 8.440 & 8.340 & 1.199 & \\
\hline & & 8.640 & 8.421 & 1.600 & \\
\hline \multirow[t]{4}{*}{3} & \multirow[t]{4}{*}{$40 \%$} & 8.770 & 8.676 & 1.083 & \multirow[t]{4}{*}{1.384} \\
\hline & & 8.810 & 8.676 & 1.544 & \\
\hline & & 8.970 & 8.828 & 1.608 & \\
\hline & & 9.010 & 8.894 & 1.304 & \\
\hline \multirow[t]{4}{*}{4} & \multirow[t]{4}{*}{$60 \%$} & 9.120 & 8.989 & 1.457 & \multirow[t]{4}{*}{1.327} \\
\hline & & 8.900 & 8.720 & 2.064 & \\
\hline & & 9.460 & 9.444 & 0.169 & \\
\hline & & 9.280 & 9.132 & 1.620 & \\
\hline \multirow[t]{4}{*}{5} & \multirow[t]{4}{*}{$80 \%$} & 9.270 & 9.140 & 1.422 & \multirow[t]{4}{*}{1.347} \\
\hline & & 9.130 & 9.040 & 0.995 & \\
\hline & & 9.290 & 9.205 & 0.923 & \\
\hline & & 9.700 & 9.505 & 2.051 & \\
\hline \multirow[t]{4}{*}{6} & \multirow[t]{4}{*}{$100 \%$} & 9.560 & 9.310 & 2.685 & \multirow[t]{4}{*}{2.612} \\
\hline & & 9.630 & 9.345 & 3.049 & \\
\hline & & 9.370 & 9.270 & 1.078 & \\
\hline & & 9.890 & 9.543 & 3.636 & \\
\hline
\end{tabular}

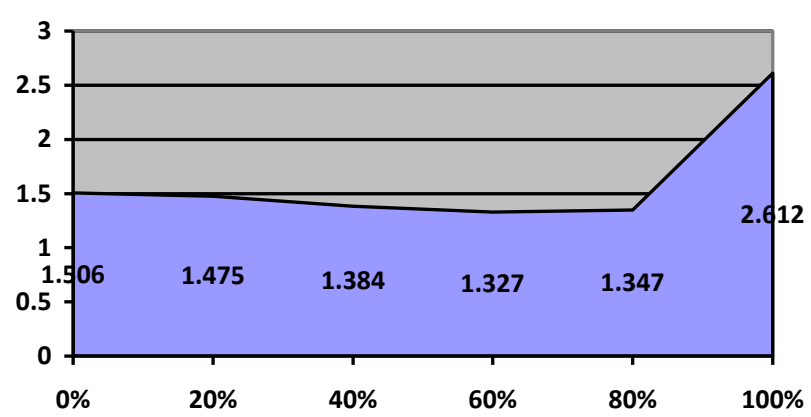

\section{Conclusion}

The use of copper slag as an alternative of great combination in concrete will increase the density of the concrete, thereby growing the weight of the concrete itself.

At the equal water-cement ratio, the workability of concrete increases as the copper slag content in the quality mixture substitute increases.
From the results of compressive strength, tensile power and flexural strength, the compressive strength of concrete is higher when copper slag is used to exchange first-class mixture by means of $40 \%$. It is therefore endorsed that $40 \%$ of the fines can be substituted with copper slag.

As the quantity of copper slag extended past $60 \%$ of the repositioning level, the surface water absorption charge reduced and the absorption charge rapidly increased.

The development enterprise is the only location for the secure use of waste. It reduces environmental issues, house problems and construction costs.

\section{References:}

[1] Naganur, B. A. 'Effect of copper slag as a partial replacement fine aggregate on the performance of cement concrete'. International Journal Research (IJR) Vol-1, Issue 8, September 2014.

[2] Rose D. A. "The effect of copper slag on strength and durability performance partially replaces the fine Ag-Gregate in concrete".

[3] International Journal of New Technology and Advanced Engineering, 5(1), 434-437, 2015.

[4] Srinivasu K. Study on compressive strength properties and effects of copper slag as a partial replacement for concrete fines. ELK Asia Pacific Journal, 2015.

[5] Zerdi T. A. "Experimental study of concrete properties using fine aggregate instead of copper slag". Global Research Analysis Magazine, 5(5), 67-69, 2016.

[6] Singh H. 'Using Copper Slag as Fine Aggregate - Case Study'. International Journal of Engineering Research and Technology Innovation, 2(5), 1-7, 2015.

[7] Patil M. V. 'Copper slag as a relocation of sand in concrete'. International Journal of Applied Engineering Research, 11(6), 4349-4353, 2016.

[8] Arivalagan.S. (year 2013). "Experimental study on flexural behavior of reinforced concrete beam as fine aggregate instead of copper slag". Journal of Civil Engi-neering and Urbanism, 3(4), 176-182.

[9] M. Maheswari, M. (2016). 'Mechanical and durability performance of reinforced concrete beams using copper slag as concrete fines'. Journal of International Studies Engineering and Technology, 3(3).

[10] Madhavi T.C. "Effect of Copper Slag on Mechanical Strength of Concrete." International Journal of ChemTech Research, 8(12), 442-449, 2015.

[11] Nataraja, M.C. 'Design of concrete mix using copper slag as fine aggregate'. International Journal of Civil Engineering, 5(9), 9099, 2014.

[12] Shi, C. "The use of copper slag in cement and concrete." Resources, Conservation and Recycling, 52, 1115-1120, 2008.

[13] IS 383 (1970): "Specification of coarse and fine aggregates for concrete natural sources" [CED 2: Cement and Concrete]. 